\title{
THE IMPACT OF CHEFS' NATIONAL CUISINE PERCEPTIONS ON THEIR INTENTION TO PURCHASE LOCAL FOOD
}

\author{
Bahattin Ozdemir ${ }^{1}$ \\ Ayla Aydin ${ }^{2}$ \\ Osman Caliskan ${ }^{3}$ \\ Gokhan Yilmaz
}

\begin{abstract}
The purpose of this study is to understand the role of chefs' perceptions of national cuisine in their intention to purchase local food. Data were collected through a survey instrument which includes individual scales for chefs' perceptions of national cuisine and their intentions to buy local food. 106 questionnaires were distributed to chefs attending to activities held by Turkish Chefs Federation in Antalya ANFAS Fairground between 26 and 28 February 2015. Within a convenient sampling method, 74 questionnaires were returned and 67 of these were included into the subsequent analyses. Following the reliability and validity analysis of the scales, the results showed that chefs perceived national cuisine in three domains as cost, labor and popularity, and the findings of regression analysis indicated that the cost dimension of national cuisine perception influenced chefs' intention to purchase local food.
\end{abstract}

Keywords: Local Food, National Cuisine, Chefs' Perceptions, Purchasing Local Food, Turkey

\section{INTRODUCTION}

As people's information sources and experiences of a wider array of local cuisines expand due to the developments in information technologies and increases in the number of travels to different regions of world, tourists are exposed to and become familiar with different cuisines (Seo et al., 2013). Relying on this familiarity, tourists develop their perceptions of different local cuisines, and it is believed that those perceptions positively influence tourists' behaviors (Chi et al., 2013). In the relevant literature it is revealed that cuisine has a considerable impact on tourists' choices of their vacation destinations (Kivelaand Crotts, 2009). Moreover, food is an important determinant of tourists' satisfaction with a destination (Nield et al., 2000). Thus, food can prompt tourists to return to the same destination (Kivela and Crotts, 2006). From a supply side perspective, tourists' food consumption is an important means of generating revenue for a destination. Additional to its economical contributions, cuisine is also a unique attribute of destinations that enhances tourist experiences (Mynttinenet al., 2015) through the connections between local food and culture.

Local food consumption is a growing trend among contemporary consumers. In a recent study, $20 \%$ of respondents rated the ingredient source as the most important attribute for their restaurant selections (Lillywhite and Simonsen, 2014). Onozaka et al. (2010) highlighted that consumers have been developing an inclination to consuming local food

\footnotetext{
${ }^{1}$ Associate Professor, Department of Gastronomy and Culinary Arts, Faculty of Tourism, Akdeniz University, Kampus Antalya, Turkey.

${ }^{2}$ Research Assistant, Department of Gastronomy and Culinary Arts, Faculty of Tourism, Akdeniz University, Kampus Antalya, Turkey.

${ }^{3}$ Assistant Professor, Department of Gastronomy and Culinary Arts, Faculty of Tourism, Akdeniz University, Kampus Antalya, Turkey.
} 
products because they perceived local food fresh, high quality and nutritious. In the specific context of tourism, prior research (Fields, 2002; Kim et al., 2009; Chang et al., 2010; Mak et al., 2012) showed that tourists are motivated to consume local food in their vacation destinations by several factors including cultural motivators (symbolic meaning of food), social motivators (status and prestige, developing new relations or strengthening existing ones around food), and physiological motivators (fresh and healthy food consumption). Local food consumption is not merely a demand side issue but also a matter of fact in the supply side. Indeed, this growing demand is expected to accelerate the production and use of local food in tourist destinations (Lillywhite and Simonsen, 2014) where hospitality industry (restaurants and hotels) is supposed to be the major users of local food products. In the context of restaurant and hotel firms, chefs play a critical role in deciding to use and purchase local food (Telfer and Wall, 2000). Therefore, the relevant literature mostly focuses on chefs' perceptions of local food products' attributes, obstacles to purchase local food, and their intention or decision to buy local foodstuffs. The researchers (Strohbehn and Gregoire, 2003; Curtis and Cowee, 2009; Onozaka et al., 2010; Kang and Rajagopal, 2014) who explored the attributes of local food revealed that chefs or decision makers (owner, general manager, purchasing manager) in hospitality industries appreciated freshness, nutritional value, quality, taste, low cost and price, uniqueness, and ease of preparation attributes of local food products. Nevertheless, chefs also experience some serious obstacles to buy or use local food. Prior research showed that seasonality of products, inconsistencies in quality and price, problems with delivery, and incomplete information about availability of products are the major challenges perceived by chefs while purchasing local food (Strohbehn and Gregoire, 2003; Curtis and Cowee, 2009; Kang and Rajagopal, 2014). Both perceptions of local products' attributes and perceptions of obstacles may influence chefs' intention to purchase local food (Inwood et al., 2009). In this sense, attributes of local food exert a positive impact on chefs' intentions while perceived obstacles negatively affect chefs' motivation to locally sourcing of food.

Another influential factor might be chefs' perceptions in the domains of local or national cuisines' ingredient, production and cost requirements and their beliefs about how customers react to local food. However, studies on the national/local cuisine perceptions are very scarce. Moreover, the respondents in the existing research studies were mainly tourists or consumers, not chefs. In fact, following the recognition that local food is a critical attribute of destinations and tourists' experiences, researchers have paid a considerable attention to tourists' perceptions of local cuisines or food. In this context, different research studies employed different conceptualizations of those perceptions. For instance, Karim and Chi (2010), Chi et al. (2013) and Seo et al. (2013) use the term "food image" while Philips et al., (2013) and Camillo and Karim (2014) prefer using "attitudes" to explain how tourists perceive local food or cuisines. According to Karim and Chi (2010) food image conceptually had three dimensions including food/cuisine (variety, quality, presentation, cooking methods, locality, and taste), dining/restaurant (price, attractiveness, varieties, easy access, friendly service, and menu) and food-related tourism activities (food and wine regions, package tours, cultural experience, street market, food vendors). However, Chi et al. (2013) stated that dimensions including food distinctiveness and accessibility, food diversity and enjoyment, and food quality and presentation constitute food image. In their study, Seo et al. (2013) empirically revealed that local food image has two dimensions: cognitive (recognition or perception of local food with its attributes including quality, attractiveness, healthfulness, family-orientation and uniqueness), and 
effective (emotional and sentimental perceptions including contention, pleasantness, enjoyable, and exiting). Philips et al. (2013) described tourists' attitudes toward a cuisine in three domains including enjoyable or not; pleasant or not; bad or good. Camillo and Karim (2014) focused on consumers' attitudes towards a national (Italian) cuisine and empirically demonstrated that taste, simplicity of cooking and preparation, freshness of ingredients, variety and appeal, price and authenticity are the main components of those attitudes. Very recently, Mynttinen et al.(2015) revealed that tourists' perception of food has two important components as freshness and healthiness. These studies also discovered positive relationships between food image, attitude or perceptions and tourists' visit intentions (Karim and Chi, 2010), sampling of local food (Philips et al., 2013; Seo et al., 2013), satisfaction with food and their evaluations of culinary experiences in a destination (Chi et al., 2013).

It is appearing that tourists'evaluations of national cuisines are important to their choices among destinations. But it is very hard to establish direct relationships between image of national cuisine based on tourists' perceptions and the purchase of local food by restaurants. Nevertheless, it is plausible to assume that positive image of a national cuisine may lead tourists to demand and consume local dishes from that food culture (Philips et al., 2013; Seo et al., 2013) and eventually tourists' increased demand may induce restaurants to include more local food into their menu offerings which may result in purchasing more locally produced foodstuffs. In fact, some researchers (Karim and Chi, 2010; Kang and Rajagopal, 2014) confirm these relations at least conceptually and partly in the way that tourists' demand for local food increases producing and serving of local dishes in local restaurants. However, the other and important aspect of local food purchases by restaurants is chefs' willingness to use local foodstuff and thus it is critical to understand the factors that have an impact on chefs' intention to buy locally produced food. As noted before, the previous research has mainly focused on the influence of chefs' perceptions of local food attributes and challenges to purchasing local food on their motivation to buy or use locally produced foodstuffs (Strohbehn and Gregoire, 2003; Curtis and Cowee, 2009; Inwood et al., 2009; Onozaka et al., 2010; Kang and Rajagopal, 2014). However, there is no research on the effects of chefs' evaluation of national cuisine on their intention to purchase local food. Since, more dishes from a national/regional cuisine on menus may require use of more local ingredients and chefs' favorable perceptions of national cuisine leads to their choices of planning menus with more varieties from national food culture. Therefore, it may be possible to associate the purchase of local food with chefs' perceptions of national/regional cuisine. Thus, the purpose of the study is to understand the role of chefs' perceptions of national cuisine in their intention to purchase local food.

\section{METHODOLOGY}

This section contains pieces of information about study setting, sampling and data collection methods and data analysis.

\section{Study Setting}

The empirical part of the study was carried out in Turkey, specifically in Antalya. Considering the number of nights spent by tourists and the number of tourism establishments, Antalya is one of the leading tourism destinations in Turkey (Erkus- 
Ozturk, 2010) and possesses the necessary resources for sun-sea-sand tourism (Alvarez, 2010). The region has a mild climate, magnificent landscapes and natural scenery, beautiful beaches and a colorful culture which attract millions of visitors every year (Cizel et al., 2013). In fact, tourism industry in Antalya is largely dependent on international tourists who are seen as "sun and sea seekers," and who visit the destination especially in the summer season (Ozdemir et al., 2012a). Tourist arrivals from foreign countries, including Germany, Russia, France, England and the Netherlands, amounted to more than 10 million people (Ozdemir et al., 2012b).

Problems, however, have emerged alongside the rapid development of tourism in Antalya. The large hotel facilities located in resort areas and are segregated from the city center. Additional to this distance between resort areas and the city center, the all-inclusive concept is a common practice among resort hotels in the region (Ozdemir et al., 2012a), and all those result in an environment in which tourists do not experience the daily life of the city and/or local people (Ozturkmen, 2005). Thus, recognition and consumption of local food by tourists visiting the region are not at a satisfactory level (Ozdemir and Kinay, 2005) which may naturally have a negative impact on the use and purchase of locally produced foodstuffs by hotels and restaurants in the region. Nevertheless, some researchers have been interested in the relationship between local food and tourism in Turkey. The Turkish literature conceptualizes the local food as a critical component of national or local culture or equates it to local or national food culture. In this context, researchers paid a considerable attention to the economical aspects of local food such as the benefits generated through marketing local products to tourists. Thus, the main subjects in the national research were the demand generating effect of local food in rural tourism (Kesici, 2012); the impact of local gastronomical products on local economical development (Kocaman and Kocaman, 2014); tourists' local food perceptions (Gokdeniz et al., 2015; BekarveBelpinar, 2015), and the role of local food in restaurant marketing (Erkol and Zengin, 2015; Yurtseven and Kaya, 2011). Although this information provides an overview of how local food was understood by researchers, it cannot present any clue in understanding the determinants of restaurants' local food purchasing behaviors. In fact, the information about how Turkish restaurants use local food products is hardly available. There is only one accessible study (Yaris and Comert, 2015) which has investigated the perceived advantages and disadvantages of using local food in restaurants with a sample of 11 restaurant operators. Therefore, there is an urge to examine the factors affecting the hotels' and restaurants' purchases of local food in larger samples in Turkey.

\section{Sampling and Data Collection}

The data were collected through a questionnaire administered to a purposive sample of Turkish chefs from hotels and restaurants operating in Antalya. Specifically, a combination of purposive sampling methods (the criterion sampling and convenience sampling) was used. The screening of study respondents followed two criteria. First, respondents had to hold upper level positions (executive chef, sous chef or chef de partie) in the kitchen and should be employed by hotel and restaurant firms operating in the region. In order to establish contact with potential respondents, two researchers attended a local food and beverage fair in ANFAS (Antalya Fair and Exhibition Organization Firm) Fairground. Respondents were approached and informed about the purpose of survey and were then asked whether they would participate in the survey. Respondents' participation in the study 
was strictly voluntary. Respondents were also told that their individual responses were anonymous and confidential. 106 questionnaires were distributed to chefs attending to activities held by Turkish Chefs Federation during the fair between 26 and 28 February 2015. Finally, 74 questionnaires were returned and 67 of these were valid for further analysis since seven respondents had completed the less than $\% 50$ of the questionnaires. It might be claimed that the current study has a relatively small sample size. However, this is the main issue in similar other studies. For example, the study by Inwood et al. (2009) involved 71 respondents into the sample while the study of Kang and Rajagopal (2014) had a sample of 40 respondents.

The questionnaire comprised three groups of items. The first group of items constitutes a scale for chefs' intention to purchase local food. In the second group, there is a scale for measuring the respondents' perceptions of national cuisine. Finally, the third section was designed to obtain demographic and professional information from the respondents.

Scale for intention to purchase local food: The items of the scale were developed by Kang and Rajagopal (2014). The authors used the conceptual framework of theory of planned behavior and examined the impact of respondents' attitudes, subjective norms, and perceived behavioral control on their intention to buy local food in the context of hotel industry in the United States. The scale originally has six items that measures respondents' intentions in the domains of cost, quality, flexibility of return policy, number of vendors, contact with vendors, and decision makers' efforts to buy locally produced food. The authors did not present any information about the dimensionality of the scale, but they involved the scale as a one-dimensional variable into the further analysis.

Scale for perceptions of national cuisine: The items of the scale were borrowed from Ozdemir (2003). The original study sampled 61 respondents who were chefs in five star hotels operating in Antalya region and measured their perceptions of Turkish, Italian and French cuisines. The 12 items in the original scale were in Turkish and related to what each cuisine requires in the domains of labor (skills, experience, specialization); cost (ingredients, equipment, labor); preparation time and craftsmanship, and popularity (consumers' interest, demand, and consumption levels). Ozdemir (2003) revealed that the scale was one-dimensional relying on the results of expletory factor analysis. All the items in the scale of chefs' intention to purchase local food were translated into Turkish from English. The translated items were examined by two experts (faculty members at gastronomy and culinary arts department) who were familiar with both languages.

The survey instrument which includes individual scales for chefs' perceptions of national cuisine and their intentions to buy local food was tested in a pilot study which was carried out with 11 chefs. After small adjustments based on the results of the pilot study, the questionnaire took its final form. A 5-point Likert scale $(1=$ strongly disagree; $5=$ strongly agree for intention to purchase, and $1=$ very low $5=$ very high for perception of national cuisine) was used for all 18 items in the both scales.

\section{Data Analysis}

Data were analyzed in several stages employing different statistical techniques. Frequencies and percentage scores were calculated for nominal variables, particularly for 
the variables with reference to demographic and professional profile of respondents. Additionally, mean scores were computed for respondents' age and tenure data. Exploratory factor analysis was used to examine validity of the scales while Cronbach's alpha coefficients were calculated to test scales' reliability. Finally, regression analysis was used to identify the relationships within data.

\section{FINDINGS}

The findings section of this study includes an evaluation of chefs' professional and demographic profile, results of reliability and validity analyses of scales, and the relationships between variables.

\section{Respondents' demographic and professional profile}

Respondents' gender, education and employment status are presented on Tab. 1. Tab. 2 shows the results of descriptive statistics about participants' age and tenure. Of the 67 respondents, $92.5 \%$ were males and half of the respondents graduated from high school. $65.7 \%$ of the respondents were employed by a hotel while majority of them $(81.8 \%)$ currently hold the position of executive chef.

Tab. 1. Information about respondents' gender, education, and employment status

\begin{tabular}{|c|c|c|c|}
\hline Variables & & Frequency & Percentage \\
\hline \multirow{3}{*}{ Gender } & Female & 5 & 7,5 \\
\hline & Male & 62 & 92,5 \\
\hline & Total & 67 & 100 \\
\hline \multirow{5}{*}{ Education } & Primary and secondary school & 19 & 29,7 \\
\hline & High school & 32 & 50 \\
\hline & College & 4 & 6,3 \\
\hline & University & 9 & 14 \\
\hline & Total & 64 & 100 \\
\hline \multirow{3}{*}{ Type of firm } & Hotel & 44 & 65,7 \\
\hline & Restaurant & 23 & 34,3 \\
\hline & Total & 67 & 100 \\
\hline \multirow{3}{*}{ Position } & Executive chef & 54 & 81,8 \\
\hline & Sous chef or chef de partie & 12 & 18,2 \\
\hline & Total & 66 & 100 \\
\hline
\end{tabular}

The mean age of the sample was 39 . The respondents averagely spent 23.71 years in the profession while the mean of total years in the current firm was slightly over 6 years as can be seen from Tab. 2 . 
Tab. 2. Information about respondents' age and tenure

\begin{tabular}{lcccc}
\hline \multicolumn{1}{c}{ Variables } & Mean & $\begin{array}{c}\text { Standard } \\
\text { deviation }\end{array}$ & Minimum & Maximum \\
\hline Age & 39,47 & 8,936 & 19 & 65 \\
\hline Total years in the profession & 23,71 & 9,219 & 8 & 53 \\
\hline Total years in the current firm & 6,65 & 5,509 & 1 & 24 \\
\hline
\end{tabular}

\section{Validity and Reliability of Scales}

This investigation analyzed the validity and reliability of scales using an exploratory factor analysis and Cronbach's alpha coefficients. Factor analyses were performed to determine the underlying dimensions of respondents' perceptions of national cuisine scale, and chefs' intention to purchase local food scale. In the factor analysis, a principal component analysis using Varimax rotation was undertaken. Factors with an eigenvalue equal to or greater than one were considered as significant and reported in the final factor structure. Only items with factor loadings of 0.5 and higher were retained for further analysis whereas items with factor loadings below 0.5 were removed. Results are depicted on Tab.3.

As a result of factor analysis for the scale of chefs' intention to purchase local food, two items ("I am willing to buy foods, if there is a flexible return policy" and "I will make an effort to purchase local foods") were deleted because of low factor loadings and the remaining four items were reduced to a single factor. As shown on Tab. 3, these four items had factor loadings ranging from 0.64 to 0.74 and one factor solution explained $48 \%$ of the total variance. The result of Bartlett's test of sphericity was significant at 0.00 ; and the Kaiser-Meyer-Olkin (KMO) overall value was 0.48 . Cronbach's alpha coefficient of the scale is 0.62 which is relatively small but still acceptable (Murphy veDavidshofer, 1988).

Similar analyses were performed for the scale of chefs' perceptions of national cuisine. Because of low factor loadings three items ("Craftsmanship needed for production of food in the cuisine"; "Specialization level of employees needed for production of food in the cuisine" and "Time needed for production of food in the cuisine") were removed following the initial factor analysis, and three factors were extracted from the remaining variables. As can be seen on Tab. 3, each factor explained $17 \%$ or more of the variance. In other words, the three factors together explained $67.5 \%$ of total variance. The result of Bartlett's test of sphericity was significant at 0.00 ; and the Kaiser-Meyer-Olkin (KMO) overall value was 0.70 . The reliability test demonstrated that the coefficients of Cronbach's alpha of three factors ranged from 0.66 to 0.84 which support the reliability. As presented on Tab.3, each of the factors was labeled based on the items that constituted it. Factor 1 included three items relating to knowledge, skills and experience levels of employees and thus labeled as "Labor". Factor 2 was also comprised of three items and was named "Cost" because the items under this factor related to cost of ingredients, labor and equipment. Factor 3 was composed of three items which were related to customers' interest, consumption and demand levels, and thus designated as "Popularity". These three factors were inserted into the further analysis as independent variables. 
Tab. 3. Results of factor analyses for two scales

\begin{tabular}{|c|c|c|c|c|}
\hline Scales and items & $\begin{array}{l}\text { Factor } \\
\text { loading }\end{array}$ & Eigenvalue & $\begin{array}{l}\text { Variance } \\
\text { explained } \\
\%\end{array}$ & $\begin{array}{l}\text { Cronbach's } \\
\text { Alpha } \\
\text { Coefficient }\end{array}$ \\
\hline Intention to purchase local food & & 1,925 & 48,132 & 62,2 \\
\hline $\begin{array}{l}\text { I will purchase more local foods, if it } \\
\text { is cost effective. }\end{array}$ & .728 & & & \\
\hline $\begin{array}{l}\text { I am willing to purchase local foods, } \\
\text { if I can receive product of consistent } \\
\text { quality. }\end{array}$ & .746 & & & \\
\hline $\begin{array}{l}\text { I will purchase local foods, if there } \\
\text { is a single point/source for } \\
\text { purchasing. }\end{array}$ & .644 & & & \\
\hline $\begin{array}{l}\text { I intend to purchase local foods, if } \\
\text { producers of local foods contact me. }\end{array}$ & .651 & & & \\
\hline \multicolumn{5}{|l|}{ Perceptions of national cuisine } \\
\hline Factor 1: Labor & & 2,501 & 27,794 & 84,6 \\
\hline $\begin{array}{l}\text { Knowledge level of employees } \\
\text { needed for production of food in the } \\
\text { cuisine }\end{array}$ & .868 & & & \\
\hline $\begin{array}{l}\text { Skills level of employees needed for } \\
\text { production of food in the cuisine }\end{array}$ & .865 & & & \\
\hline $\begin{array}{l}\text { Experience level of employees } \\
\text { needed for production of food in the } \\
\text { cuisine }\end{array}$ & .825 & & & \\
\hline Factor 2: Cost & & 1,987 & 22,081 & 72,1 \\
\hline $\begin{array}{l}\text { Cost of ingredients used in the } \\
\text { production of food in this cuisine }\end{array}$ & .857 & & & \\
\hline $\begin{array}{l}\text { Cost of equipment used in the } \\
\text { production of food in this cuisine }\end{array}$ & .843 & & & \\
\hline $\begin{array}{l}\text { Cost of labor used in the production } \\
\text { of food in this cuisine }\end{array}$ & .675 & & & \\
\hline Factor 3: Popularity & & 1,587 & 17,633 & 66,7 \\
\hline $\begin{array}{l}\text { Level of food consumed by } \\
\text { customers }\end{array}$ & .834 & & & \\
\hline Customers' demand for food & .641 & & & \\
\hline Customers' interest in food & .582 & & & \\
\hline
\end{tabular}

\section{Testing the relations between dependent and independent variables}

Prior to performing the regression analysis, Pearson Correlationanalysis was conducted in order to diagnose the relationshipsbetweenchefs' intention to purchase local food and dimensions of chefs' perceptions of national cuisine. As seen on Tab. 4, cost (Correlation coefficient $=-, 372 ; p=0,007)$ is negatively and significantly correlated to chefs' intention 
to purchase local food while popularity (Correlation coefficient $=, 351 ; p=0,007$ ) has a significant and positive correlation. Results also indicated that there was not a significant relationship betweenlabor and intention to purchase local products. Thus, only two variables (cost and popularity) were entered into the forthcoming regression analysis.

Tab. 4. Correlations between dependent variable and independent variables

\begin{tabular}{lcc}
\hline $\begin{array}{l}\text { Chefs' perceptions of national } \\
\text { cuisine }\end{array}$ & $\begin{array}{c}\text { Pearson Correlation } \\
\text { coefficients }\end{array}$ & Significance \\
\hline Labor &,- 065 &, 634 \\
\hline Cost &,- 372 &, $007^{*}$ \\
\hline Popularity &, 351 &, $007^{*}$ \\
\hline
\end{tabular}

* Correlation is significant at the 0.01 level (two-tailed).

A multiple linear regression analysis was used to test the prescribed relationships between independent variables (two dimensions of chefs' perception of national cuisine: cost and popularity) and dependent variable (chefs' intention to purchase local food) of the current research. Results are shown on Tab. 5 .

Tab. 5. Results of regression analysis

\begin{tabular}{cccccc}
\hline Variables & $\begin{array}{c}\text { Standardized } \\
\text { Coefficients }\end{array}$ & $\begin{array}{c}\mathbf{t} \\
\text { value }\end{array}$ & Significance & Tolerance & VIF \\
\hline Popularity &, 219 & 1,796 &, 077 &, 870 & 1,149 \\
\hline Cost &,- 282 & $-2,314$ &, 024 &, 870 & 1,149 \\
\hline $\mathrm{R}$ & & &, 415 & & \\
\hline $\mathrm{R}^{2}$ & & &, 172 & & \\
\hline Durbin-Watson value & & & 1,997 & & \\
\hline
\end{tabular}

Dependent variable: Chefs' intention to purchase local food

Since the assumption of normality needs to be checked for parametric tests, before conducting regression analysis, the variables were tested against distribution for normality by using Kolmogorov-Smirnov test and skewness and kurtosis values. Depending on the results for cost (Kolmogorov-Smirnov $\mathrm{Z}=0,818, \mathrm{p}=, 516$; skewness = ,463; kurtosis= ,432); popularity (Kolmogorov-Smirnov $Z=1,056, \mathrm{p}=$,215; skewness $=-, 830$; kurtosis= 1,266) and intention to purchase local food (Kolmogorov-Smirnov $Z=1,249, p=, 088$; skewness $=-, 595$; kurtosis $=-, 008)$, it is possible to claim that the normality assumption was not violated. Following the guidelines provided by Field (2009), assumptions of regression model including the linearity between dependent and independent variables, homoscedasticity (homogeneity of variance), autocorrelations (statistical independence of errors) and multicollinearity (highly correlated independent variables) were checked through examination of residual plots (plots of the standardized residuals as a function of standardized predicted values), Durbin Watson test, and examination of tolerance and variance inflation factors (tolerance and VIF). A visual inspection of scatter plots did not indicate a serious problem of violation of linearity and homoscedasticity assumptions. As a 
rule of thumb, Durbin Watson test values between 1 and 3 indicate that there is no autocorrelation in the data. As seen on Tab. 5, the result of Durbin Watson test secures that the regression model in the current study did not suffer from a violation of autocorrelation assumption. The values of VIF $\geq 10$ and tolerance $<0.10$ indicate that multicollinearity exists among independent variables. Tab. 5 where the regressionanalysis results are depicted shows that the current regression model has not a multicollinearity problem since the VIF values are below 10 and tolerance values are above 0.10 . The regression model shown on Tab. 5 demonstrated that although popularity $(t=1,796 ; p=0,077)$ did not have any significant effect, the cost $(=-2,314 ; p=.024)$ dimension of chefs' perceptions of national cuisine had an significant impact on the intention to purchase local food. It can also be seen that cost had a negative and relatively small size effect on chefs' intentions when its $\beta$ value $(-, 282)$ was scrutinized. The $\mathrm{R}^{2}$ value of the model is considerably low, which indicates that cost alone can only explain a small portion of variance in chefs' intention to buy local food.

\section{CONCLUSIONS}

In recent years, a growing emphasis has been placed on local food both from tourist demand and tourism supply perspectives, and it has become a popular research subject among hospitality and tourism researchers. From a supply side perspective, one of the common dependent variables of prior research was chef's motivation to buy or use locally produced foodstuffs, and this variable was mainly associated with a plenty of factors from two major domains as chefs' perceptions of local food attributes and challenges to purchasing local food. The current study has taken an alternative approach and focused on chefs' local cuisine perceptions as an independent variable. Thus, the purpose of the study was to understand the impact of chefs' perceptions of national cuisine on their intention to purchase local food.

The major findings of the study revealed that cost, labor and popularity constituted the chefs' perception of national cuisine. Moreover, the regression model demonstrated that the cost dimension of chefs' national cuisine perception is a predictor of their intention to purchase local food. Thus, when chefs' perceive that national cuisine requires high level of costs with reference to ingredients, equipment and labor; they are less inclined to develop a strong intention to buy local food products. Although the popularity was not a significant determinant of chefs' intentions in the regression model, it was significantly and positively associated with chefs' intention according to correlation analysis. Thus, popularity has also a potential to influence chefs' intention to buy local food. More specifically, chefs' positive beliefs that costumers are interested in national cuisine, and also demand and consume the food from national food culture may strengthen their intention to use and purchase local food.

The major findings of this study have some important implications for practice. First, efforts should be oriented to elimination of obstacles to purchasing local food in order to increase the use of local foodstuffs by restaurants or hotels in a destination. According to prior research there might be a plenty of obstacles, but the current study demonstrated that chefs' perception of costs of a national cuisine is also a hindering factor to buy local food. Despite its costs, national cuisine is a fruitful source for innovative ideas in the kitchen. Chefs may focus on generating innovative versions of classical dishes in the national 
cuisine, and these new dishes may be produced by using local food. Thus, it is important to educate chefs about the innovation potential of national cuisine which may lessen its cost burden and increase the use of local food. Second, popularity of a national cuisine among tourists and demand generating potential of local food are important attributes that may entice chefs to use and purchase local products. In this sense, one strategy might be to promote local/national cuisines among tourists. The increased demand to local food by tourists may lead chefs to have positive beliefs about tourists' local food consumption behaviors, and eventually may positively influence their intention to buy local food products.

The current study has some limitations. First, the convenient sampling method and relatively small sample size which is limited to a specific destination is a serious restriction to generalize findings to larger populations. Nevertheless, as a suggestion for future research, researchers may involve larger samples in different destinations and obtain new findings that might be compared to the findings of the current study. Another meaningful limitation of the present study is the small $\mathrm{R}^{2}$ value of the regression model which indicates that the independent variable can only explain a small portion of variance in the dependent variable. Thus, there are other factors that have a considerable effect on the dependent variable. Therefore, future research studies may insert new variables (attributes of local food, challenges to buy local food, respondents' demographic and professional profiles) into the model in order to increase the explanatory strength of their models.

\section{REFERENCES}

1. Alvarez, M.D. (2010). Marketing of Turkey as a Tourism Destination. Anatolia: An International Journal of Tourism and Hospitality Research, 21(1), 123-138.

2. Bekar, A., Belpınar, A. (2015). Turistlerin Gastronomi Turizmine İliskin Goruslerinin Milliyetlerine Gore Degerlendirilmesi (The Evaluation of Tourist Opinions on Gastronomy Tourism in Terms of Their Nationalities). Journal of Yasar University, 10(38), 6478-6554.

3. Camillo, A., Shahrim, M., Karim, A.B. (2014). Consumer Attitudes and Perceptions towards Western Cuisine: A Strategic Investigation of the Italian Restaurant Industry in Malaysia. Journal of Foodservice Business Research, (17), 103-121.

4. Chang, R.C., Kivela, J., Mak, A.H. (2010). Food Preferences of Chinese Tourists. Annals of Tourism Research, 37(4), 989-1011.

5. Chi, G-Q.C., Chua, B.L., Othman, M., Karim, S.A. (2013). Investigating the Structural Relationships between Food Image, Food Satisfaction, Culinary Quality, and Behavioral Intentions: The Case of Malaysia. International Journal of Hospitality \&Tourism Administration, (14), 99-120.

6. Cizel R.B., Cizel, B., Sarvan, F., Ozdemir, B. (2013). Emergence and Spread of All-Inclusive System in the Turkish Tourism Sector and Strategic Responses of Accommodation Firms, International Journal of Hospitality \& Tourism Administration, 14:4, 305-340.

7. Curtis, K.R., Cowee, M.W. (2009). Direct Marketing Local Food to Chefs: Chef Preferences and Perceived Obstacles. Journal of Food Distribution Research, 40 (2), 26-36. 
8. Erkol, G., Zengin, B. (2015). Sanlıurfa'da Bulunan Yoresel Yiyecek-Icecek Isletmelerinin Pazarlama Stratejilerinin Sehrin Turizm Acisindan Pazarlanabilirligine Etkileri (The Effects of Food Culture and Food and Beverage Marketing Strategies of Sanliurfa on Marketing in Terms of Tourism According to Local Food and Beverage Enterprises Perspective). Akademik Sosyal Arastirmalar Dergisi, 3(9), 599-614.

9. Erkus-Ozturk, H. (2010). Planning of Tourism Development: The case of Antalya. Anatolia: An International Journal of Tourism and Hospitality Research, 21(1), 107-122.

10. Field, A. (2009). Discovering Statistics: Using SPSS, Los Angeles: Sage.

11. Fields, K. (2002). Demand for the Gastronomy Tourism Product: Motivational Factors. A.M. Hjalager and G. Richards (Ed), Tourism and Gastronomy. 36-50. Londra: Routledge.

12. Gokdeniz, A., Erdem, B., Dinc, Y., Uguz, S.C. (2015). Gastronomi Turizmi: Ayvalik'ta Yerli Turistler Uzerinde Gorgul Bir Arastirma (Gastronomy Tourism: An Empirical Study on Domestic Tourists in Ayvalık). Journal of Tourism and Gastronomy Studies, 3(1), 14-29.

13. Inwood, S.M., Sharp, J.S., Moore, R.H., Stinner, D.H. (2009). Restaurants, Chefs and Local Foods: Insights Drawn from Application of a Diffusion of Innovation Framework. Agriculture and Human Value, 26, 177-191.

14. Kang, S., Rajagopal, L. (2014). Perceptions of Benefits and Challenges of Purchasing Local Foods among Hotel Industry Decision Makers. Journal of Foodservice Business Research, 17 (4), 301-322.

15. Karim, S.A., Chi, C.G.Q. (2010). Culinary Tourism as a Destination Attraction: An Empirical Examination of Destinations' Food Image. Journal of Hospitality Marketing \& Management, 19, 531-555.

16. Kesici, M. (2012). Kirsal Turizme Olan Talepte Yoresel Yiyecekve Icecek Kulturunun Rolu. (The Role of Traditional Food and Beverage Culture Concerning to Demand of Rural Tourism) KMU Sosyalve Ekonomik Arastirmalar Dergisi, 14 (23), 33-37.

17. Kim, Y.G., Eves, A., Scarles, C. (2009). Building a Model of Local Food Consumption on Trips and Holidays: A Grounded Theory Approach. International Journal of Hospitality Management, 28, 423-431.

18. Kivela, J. Crotts, J.C. (2006). Tourism and Gastronomy: Gastronomy's Influence on How Tourists Experience a Destination. Journal of Hospitality and Tourism Research, 30. (3), 354-377.

19. Kivela, J., Crotts, J.C. (2009). Understanding Travelers' Experiences of Gastronomy through Etymology and Narration. Journal of Hospitality \& Tourism Research, 33 (2), 161-192.

20. Kocaman, M., Kocaman, E.M. (2014). The Importance of Cultural and Gastronomic Tourism in Local Economic Development: Zile Sample. International Journal of Economics and Financial Issues, 4 (4), 735-744.

21. Lillywhite, J.M., Simonsen, J.E. (2014). Consumer Preferences for Locally Produced Food Ingredient Sourcing in Restaurants. Journal of Food Products Marketing, 20, 308-324.

22. Mak, A.H., Lumbers, M., Eves, A., Chang, R.C. (2012). Factors Influencing Tourist Food Consumption. International Journal of Hospitality Management, 31, 928-936. 
23. Murphy, K.R., Davidshofer, C.O. (1988). Psychological Testing: Principles and Applications. Englewood Cliffs, NJ: Prentice Hall.

24. Mynttinen, S., Logren, J., Sarkka-Tirkkonen, M., Rautiainen, T. (2015). Perceptions of Food and its Locality among Russian Tourists in the South Savo Region of Finland. Tourism Management, (48), 455-466.

25. Nield, K., Kozak, M., LeGrys, G . (2000). The Role of Food Service in Tourist Satisfaction. Hospitality Management, (19), 375-384.

26. Onozaka, Y., Nurse, G., McFadden, D.T. (2010). Local Food Consumers: How Motivations and Perceptions Translate to Buying Behavior. Choices: The Magazine of Food, Farm and Resource Issues, 25(1).

27. Ozdemir, B. (2003). Antalya Yoresindeki Konaklama Isletmelerinde Turk, Fransizve Italyan Mutfaklarinin Karsilastirilmasina Yonelik Bir Arastirma (Research on the Comparison of Turkish, French and Italian Cuisines in Lodging Operations in the Antalya Region), DAU Turizm Arastirmaları Dergisi. 4, 37-58.

28. Ozdemir, B.,Kinay, F. (2004). Yabanci Ziyaretcilerin Turk Mutfagına Iliskin Gorusleri: Antalya'yi Ziyaret Eden Almanve Rus Turistler Uzerine Bir Arastirma (Attitudes of Foreign Visitors Towards Turkish Cuisine: Research on German and Russian Tourists Visiting Antalya), Gazi Universitesi Ticaretve Turizm Egitim Fakultesi Dergisi ,Cilt 2, 5-28.

29. Ozdemir, B., Cizel, B., Cizel, R.B., Içigen, E. (2012a). Satisfaction with AllInclusive Tourism Resorts: The Effects of Satisfaction with Destination and Destination Loyalty. International Journal of Hospitality \& Tourism Administration, 13:2, 109-130.

30. Ozdemir, B., Aksu, A., Ehtiyar, E., Cizel, B., Cizel, R.B., Içigen, E. (2012b). Relationships among Tourist Profile, Satisfaction and Destination Loyalty: Examining Empirical Evidences in Antalya Region of Turkey. Journal of Hospitality Marketing \& Management, 21:5, 506-540.

31. Ozturkmen, A. (2005). Turkish Tourism at the Door of Europe: Perceptions of Image in Historical and Contemporary Perspectives. Middle Eastern Studies, 41(4), 605-621.

32. Phillips, J.W., Asperin, A., Wolfe, K. (2013). Investigating the Effect of Country Image and Subjective Knowledge on Attitudes and Behaviors: U.S. Upper Midwesterners' Intentions to Consume Korean Food and Visit Korea. International Journal of Hospitality Management, (32), 49-58.

33. Seo, S., Kim, O.Y., Oh, S., Yun, N. (2013). Influence of Informational and Experiential Familiarity on Image of Local Foods. International Journal of Hospitality Management, (34), 295-308.

34. Sharma, A., Gregoire, M.B., Strohbehn, C. (2009). Assessing Costs of Using Local Foods in Independent Restaurants. Journal of Foodservice Business Research, 12 (1), 55-71.

35. Strohbehn, C. H., Gregoire, M.B. (2003). Case Studies of Local Food Purchasing by Central Iowa Restaurants and Institutions. Foodservice Research International, 14(1), 53-64.

36. Telfer, D.J., Wall, G. (2000). Strengthening Backward Economic Linkages: Local Food Purchasing by Three Indonesian Hotels. Tourism Geographies, 2(4), 421447.

37. Yaris, A., Comert, M. (2015). Mardin Ilindeki Restoranlarin Yerel Urun Kullanımindaki Avantajve Dezavantajlari Ile Ilgili Algi Duzeyleri (Restaurant 
Operators' Perceptions of Advantages and Disadvantages of Using Local Products in Mardin). Uluslararasi Sosyal Arastirmalar Dergisi, 8 (37), 991-998.

38. Yurtseven, H.R., Kaya, O. (2011). Local Food in Local Menus: The Case of Gokceada. Tourismos: An International Multidisciplinary Journal of Tourism, 6(2), 263-275. 